\title{
MR breast imaging: a comparative analysis of conventional and parallel imaging acquisition
}

\section{RM delle mammelle: confronto tra tecnica convenzionale ed imaging parallelo}

\author{
A. Orlacchio • F. Bolacchi • A. Rotili • E. Cossu • I. Tanga • V. Cozzolino • G. Simonetti \\ Dipartimento di Diagnostica per Immagini, Imaging Molecolare, Radiologia Interventistica e Radioterapia, Policlinico Universitario \\ "Tor Vergata", Viale Oxford 81, 00133 Roma, Italy \\ Correspondence to: A. Orlacchio, Tel.: +39-06-20902400-1, Fax: +39-06-20902404, e-mail: aorlacchio@uniroma2.it, \\ aorlacchio@sirm.org
}

Received: 11 April 2007 / Accepted: 6 September 2007

C) Springer-Verlag 2008

\begin{abstract}
Purpose. The objective of this study was to compare conventional breast magnetic resonance imaging (MRI) with breast MRI acquired with the sensitivity-encoding (SENSE) technique on a 1.5-T MRI scanner in the same patient, on the basis of image quality and kinetics analysis.

Materials and methods. Thirty-one patients with suspicious mammography and US findings were included in the study. Conventional breast MRI consisted of the following sequences: T1 (matrix, $288 \times 512$ ); T2 (matrix $225 \times 512$ ); short tau inversion recovery (STIR) (matrix $320 \times 224)$ and dynamic T1 [2D fast-field echo (FFE)] (matrix 256 $\times 512$; temporal resolution $\leq 80$ s). The SENSE technique included the following sequences: T1 (matrix $512 \times 512$ ); T2 (matrix 512×512); short-tau inversion recovery (STIR) (matrix 320×224); dynamic T1 (3D FFE) (matrix $512 \times 512$, with a temporal resolution $\leq 70 \mathrm{~s}$ ). Image quality was graded on a four-point scale, and the mean scores given to each sequence were compared between the two protocols. The relative enhancement rates and the qualitative features of the signal intensity (SI)/time curves were also compared between the two protocols.

Results. The readers found 64 contrast-enhanced lesions in 31 patients. Nineteen patients had a total of 27 malignant lesions. In the remaining 12 patients, 37 benign lesions were found. No significant differences between the two protocols were observed with regard to the mean relative enhancement rates and the qualitative features of the SI/time curves. In detail, the mean image quality scores
\end{abstract}

\begin{abstract}
Riassunto
Obiettivo. Confrontare in termini di qualità di immagine e analisi cinetica l'esame di risonanza magnetica (RM) mammaria convenzionale con l'esame RM acquisito con la tecnica dell'imaging parallelo con scanner RM 1,5 T nello stesso gruppo di pazienti.
\end{abstract}

Materiali e metodi. Trentuno pazienti con sospetta lesione maligna all'esame mammografico ed ecografico hanno effettuato sia un esame di RM mammaria convenzionale che un esame RM acquisito con tecnica SENSE. L'esame convenzionale era caratterizzato dalle seguenti sequenze: T1 (matrice 288 $\times 512$ ); $T 2$ (matrice $225 \times 512$ ), da una short tau inversion recovery (STIR) (matrice $320 \times 224)$ e da una sequenza T1 (2D FFE) dinamica post contrasto (matrice 256×512; risoluzione temporale $\leq 80 \mathrm{~s}$ ). L'esame acquisito con il SENSE era costituito da una sequenza T1 (matrice

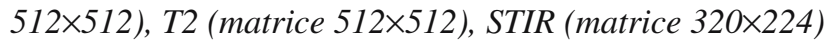
e una sequenza dinamica T1 (3D FFE) (matrice 512×512, con una risoluzione temporale $\leq 70 \mathrm{~s}$ ). La qualità dell'immagine è stata valutata assegnando a ciascuna sequenza un punteggio da 1 a 4 e $i$ valori medi assegnati a ciascuna sequenza sono stati comparati tra $i$ due protocolli. Sono stati comparati anche $i$ valori medi di intensità relativa del segnale e le caratteristiche qualitative delle curve cinetiche.

Risultati. Sono state documentate 64 lesioni in 31 pazienti. 27 lesioni maligne erano presenti in 19 pazienti. In 12 pazienti sono state evidenziate 37 lesioni benigne. Non è stata dimostrata una differenza statisticamente significativa tra i due protocolli per quanto riguarda 
were higher for SENSE imaging $(p<0.05)$. The mean image quality score for the T1 and T2 morphological sequences were comparable. In contrast, the quality scores for the STIR images differed significantly between the two protocols $(p<0.001)$, and a significant difference was also observed when comparing the $\mathrm{T} 1$ postcontrast images $(p<0.001)$.

Conclusions. Our data suggest that the SENSE imaging protocol applied in our study is superior to conventional imaging with regard to image quality, especially for T1 postcontrast and STIR images. SENSE imaging protocols may provide an alternative to conventional sequences for contrast-enhanced MRI of the breast using 1.5-T MR scanners.

Keywords: Breast cancer $\cdot$ CE-MRI $\cdot$ SENSE $\cdot$ Parallel imaging l'intensità relativa del segnale e le caratteristiche qualitative delle curve cinetiche. Complessivamente la qualità delle immagini acquisite con la tecnica SENSE è risultata essere superiore rispetto a quelle acquisite con tecnica convenzionale $(p<0,05)$. In particolare, non è stata osservata nessuna differenza statisticamente significativa tra i due protocolli per quanto riguarda le sequenze morfologiche T1 e T2 pesate. Al contrario una differenza statisticamente significativa è stata dimostrata tra i due protocolli per quanto riguarda la qualità delle immagini delle sequenze STIR e di quelle TI dopo contrasto acquisite con tecnica SENSE, rispetto a quelle acquisite con il protocollo convenzionale $(p<0,001)$.

Conclusioni. I risultati del nostro studio suggeriscono che il protocollo SENSE da noi utilizzato, mostrando una qualità di immagine superiore rispetto al protocollo convenzionale soprattutto per le sequenze STIR e TI dopo mezzo di contrasto, possa essere considerato una valida alternativa ai protocolli di imaging tradizionale nella RM mammaria effettuata con scanner RM 1,5 T.

Parole chiave Carcinoma mammario $\cdot R M$ dinamica con $m d c \cdot$ SENSE $\cdot$ Imaging parallelo

\section{Introduction}

Over the past decades, important advances have been made in the field of magnetic resonance imaging (MRI) of the breast up to more recent experience that has demonstrated not only that breast cancer can be visualised on MR images but also that mammographically and clinically occult breast cancer can be detected on MR images [1-3]. It has become increasingly clear that the diagnostic criteria for breast lesion characterisation are based either on morphologic features and enhancement kinetics using contrast-enhanced dynamic MR images [4-6]. These criteria, however, require a technique that offers not only a high spatial resolution but also a high temporal resolution [7, 8]. High-spatial-resolution images must be acquired within a short period to assess both lesion morphology and kinetic pattern. Unfortunately, these two criteria are competing demands, and new MRI strategies are required to reconcile these two divergent necessities [9]. Developments have been made in surface coil technology, resulting in improved spatial resolution and imaging protocols and reduced acquisition time [10]. The latest development in MRI is parallel imaging, a group of techniques that take advantage of the spatial information inherent in phased-array radiofrequency coils. Sensitivity encoding (SENSE) is one of the parallel reconstruction technique that allows reduced image acquisition time by using multiple receiver coil elements [11]. The aim of our study

\section{Introduzione}

Negli ultimi decenni, sono stati compiuti numerosi progressi nel campo della risonanza magnetica (RM) delle mammelle, fino alle più recenti esperienze che hanno dimostrato come la RM, oltre ad essere un esame diagnostico complementare all'Imaging convenzionale nella diagnosi del carcinoma mammario, consente di evidenziare lesioni occulte alle indagini mammografiche ed ecografiche [1-3]. È ormai consolidato che i criteri diagnostici per la caratterizzazione RM delle lesioni mammarie si basino sulla valutazione congiunta della morfologia e del pattern cinetico di enhancement che le lesioni presentano allo studio RM dinamico con mezzo di contrasto [4-6]. Tale valutazione, tuttavia, richiede una tecnica che offra non solo un'elevata risoluzione spaziale ma anche un'elevata risoluzione temporale [7, 8]. Risoluzioni spaziali elevate devono essere acquisite in intervalli di tempo breve, per poter caratterizzare con accuratezza il pattern cinetico di enhancement delle lesioni. Tuttavia risoluzione spaziale e temporale sono in conflitto e nuove strategie RM sono necessarie al fine di ottimizzare $i$ protocolli RM [9]. Recentemente, sono stati compiuti numerosi progressi nella tecnologia delle bobine di superficie che hanno portato allo sviluppo di nuovi e più efficaci protocolli d'acquisizione con un conseguente incremento della risoluzione spaziale ed una riduzione dei tempi di acquisizione [10]. Il più recente sviluppo tecnologico per la ridu- 
was to compare conventional breast MRI and breast MRI acquired with the SENSE technique on a $1.5 \mathrm{~T}$ scanner in the same patients, on the basis of image quality and kinetics analysis.

\section{Materials and methods}

Patients

The study group included 31 patients (mean age 53 years; age range 40-74) with X-ray mammography and ultrasonography (US) suspicious for malignancy. When a multifocal/multicentric disease was present, only the lesion with the greatest diameter was evaluated by core biopsy. Additional foci were characterised by direct surgical excision. All lesions classified as malignant or atypical hyperplasia at core biopsy underwent surgical excision. All lesions classified as benign at core biopsy and lesions with a low level of suspicion on conventional imaging and MRI were followed up by MRI and mammography for at least 12 months. The study was approved by our institutional review board, and all patients gave their written informed consent.

Magnetic resonance technique

All MRI examinations were performed on a 1.5-T wholebody MRI system (Intera, Philips Medical Systems, Best, The Netherlands) twice: once with the standard dynamic protocol, and once with the use of sensitivity-encoding (SENSE) technology. For the standard dynamic protocol, a standard double breast coil was used. Each patient was examined in the prone position. Images were acquired in the axial plane. After a survey scan, the following MRI sequences were acquired: T1 [turbo spin echo (TSE)] (TR/TE $6.8 / 3.3 \mathrm{~ms}$; thickness $3 \mathrm{~mm}$, no intersection gap; matrix, 288 $\times 512$ ); T2 (TSE) (TR/TE 3,800/140 ms; thickness 3 $\mathrm{mm}$, no intersection gap; matrix, $225 \times 512$ ); short tau inversion recovery (STIR) (TR/TE/TI/ 4,000/42/155 ms; $3.0 \mathrm{~mm}$ thickness, no interslice spacing; matrix, $320 \times 224)$ and dynamic T1 (2D) [fast-field echo (FFE)] (TR/TE 290/4.6 ms; flip angle $90^{\circ}$; matrix, 256 $\times 512$; thickness $3 \mathrm{~mm}$; six dynamic scans with a temporal resolution $\leq 80 \mathrm{~s}$ for each scan). All patients underwent the second MR examination using SENSE technology within 7-15 days from the first examination. The images were acquired using a dedicated four-element SENSE-compatible breast surface coil with a SENSE factor of two. After performing a survey scan and a reference scan, the following sequences were acquired: T1 (TSE) (TR/TE 6.8/3.3 ms; thickness $2.5 \mathrm{~mm}$, no intersection gap; matrix, $512 \times 512$ ); T2 (TSE) (TR/TE $3,800 / 140 \mathrm{~ms}$; thickness $2.5 \mathrm{~mm}$, no intersection gap; matrix, $512 \times 512$ ); STIR (TR/TE/TI/ 4,000/42/155 ms; $2.5 \mathrm{~mm}$ thickness, no inter- zione dei tempi di acquisizione nell'imaging RM è rappresentato dall'imaging parallelo la cui tecnica più diffusa si chiama codifica della sensibilità (SENSitivity Encoding, SENSE). La riduzione temporale è ottenuta attraverso un sottocampionamento dello spazio-k utilizzando la registrazione simultanea di immagini provenienti da bobine di superficie multicanali [11]. Lo scopo del nostro studio è stato quello di confrontare, in termini di qualità di immagine e di analisi cinetica, l'imaging RM convenzionale delle mammelle con l'imaging RM acquisito con tecnica SENSE, nello stesso gruppo di pazienti utilizzando uno scanner RM a $1,5 \mathrm{~T}$.

\section{Materiali e metodi}

Pazienti

Sono state esaminate 31 pazienti (età media 53 anni, età compresa tra 40-74 anni) con sospetto di neoplasia all'imaging mammografico ed ecografico. Nel caso di malattia multifocale/multicentrica, solo la lesione di maggiori dimensioni è stata valutata mediante core biopsy. I foci addizionali sono stati caratterizzati mediante escissione chirurgica. Tutte le lesioni classificate come maligne o come iperplasia atipica all'agobiopsia percutanea sono andate incontro ad intervento chirurgico. Le lesioni che sono state classificate come benigne alla core biopsy o che all'imaging convenzionale e RM mostravano un basso sospetto di malignità, sono state sottoposte a follow-up RM e mammografico con cadenza annuale. Lo studio è stato approvato dal nostro dal nostro Comitato Etico. Tutte le pazienti hanno firmato un consenso informato allo studio.

\section{Tecnica RM}

Gli esami RM sono stati eseguiti con un'apparecchiatura RM a 1,5 T (Intera, Philips Medical Systems, Best, Olanda). Tutte le pazienti sono state sottoposte all'esame RM due volte, una volta utilizzando una tecnica standard e l'altra utilizzando la tecnologia SENSE. Per l'esame convenzionale è stata usata una bobina dedicata per lo studio delle mammelle. Ciascuna paziente è stata esaminata in posizione prona con entrambe le mammelle adagiate all'interno della bobina. Sono state acquisite immagini RM sui piani assiali. Il protocollo RM utilizzato, preceduto dall'acquisizione di una survey, ha incluso sequenze: T1 (TSE) (TR/TE 6,8/3,3 ms; spessore, $3 \mathrm{~mm}$, gap 0; matrice, 288×512); T2- TSE (TR/TE 3800/140 ms; spessore, $3 \mathrm{~mm}$, gap 0; matrice, 225×512); una sequenza short tau inversion recovery (STIR) (TR/TE/TI/ 4,000/42/155 ms; $3 \mathrm{~mm}$ spessore, gap 0; matrice 320×224) ed una sequenza dinamica T1 (2D) (FFE) (TR/TE 290/4,6 ms; flip angle, $90^{\circ}$; matrice 256 $\times 512$; spessore, $3 \mathrm{~mm}$; $6 \mathrm{di}$ - 
slice spacing; matrix, $320 \times 224)$ and a dynamic T1 (3D) (FFE) (TR/TE 7.9/3.9 ms; flip angle $25^{\circ}$; matrix 512×512; thickness $2.5 \mathrm{~mm}$; eight dynamic scans; with a temporal resolution $\leq 70$ s for each scan). All T1 dynamic sequences were acquired after a bolus injection of $0.1 \mathrm{mmol} / \mathrm{kg}$ of gadolinium dimeglumine (Magnevist; Schering, Berlin, Germany) at an injection rate of $2 \mathrm{ml} / \mathrm{s}$, followed by a $20-\mathrm{ml}$ saline flush.

\section{Data analysis}

All exams were analysed by two radiologists experienced in interpreting breast MRI. The radiologists were blinded to the imaging technique. Previous mammograms and US images were available during the reading session. Each observer recorded morphological characteristics such as lesion shape (round, oval, irregular or stellate), margins (smooth, irregular or spiculated) and internal architecture (homogeneous, heterogeneous, enhancement or low-signal intensity internal septations). Enhancing lesions were identified on subtracted images and were further evaluated by using a region-of-interest (ROI)-based analysis. Manually drawn ROIs ( $3 \times 3$ pixels) were positioned within the suspicious lesion on the areas of maximal enhancement. Lesion signal intensity was plotted versus time to yield the signal intensity time curve. Quantitative assessment of lesion relative enhancement rates were calculated according to the pattern: [(post-contrast Signal Intensity (SI) - precontrast SI)/pre-contrast SI] $\times 100(\%)$. The qualitative features of the si/time curves, such as the presence of persistent enhancement (type 1), plateau (type 2) or washout (type 3), were analysed as described elsewhere [12]. MRI findings, according to the Fisher score, were classified into Breast Imaging-Reporting and Data System (BI-RADS) categories [12]

Image quality analysis

For the prospective analysis of image quality, all images were transferred to a workstation and were displayed with standardised window settings. Images were displayed in a pairwise fashion to allow direct comparison of images obtained with the standard protocol and the SENSE protocol. Readers were blinded to the protocol with which the respective images were acquired. Image quality was subjectively rated on a scale of 1 (poor image quality) to 4 (excellent) on the basis of the presence or absence of radiofrequency (RF) inhomogeneity artefacts, motion and susceptibility artefacts. RF inhomogeneity artefacts were defined as the presence of an undesired variation in signal intensity across the image due to a nonuniform $B_{1}$ field or an nonuniform sensitivity in the receive-only coil. Motion artefacts (such as patient motion, respiratory or cardiac motions and vascular pulsations) were defined either as the motion of the entire object during namiche; con risoluzione temporale $\leq 80$ s per ciascuna dinamica). L' esame RM acquisito con tecnica SENSE è stato effettuato entro $7 \times 15$ giorni dall'esecuzione dell'esame acquisito con tecnica convenzionale. L'esame è stato effettuato utilizzando una bobina dedicata per la mammella a 4 canali con fattore SENSE 2. Successivamente all'acquisizione della survey e della reference scan, sono state acquisite le seguenti sequenze: Tl (TSE) (TR/TE 6,8/3,3 ms; spessore, 2,5 mm, gap 0; matrice, 512×512); T2 (TSE) (TR/TE 3800/140 ms; spessore, 2,5 mm, gap 0; matrice, 512×512); una sequenza short tau inversion recovery (STIR) (TR/TE/TI/ 4,000/42/155 ms; 2,5 mm spessore, gap 0; 320×224 matrice) ed un'acquisizione dinamica $T 1$ (3D) (FFE) (TR/TE 7,9/3,9 ms; flip angle, $25^{\circ}$; matrice $512 \times 512$; spessore, $2,5 \mathrm{~mm}$; 8 dinamiche; con una risoluzione spaziale $\leq 70$ s per ciascuna dinamica). Tutte le sequenze T1 dinamiche sono state acquisite previa iniezione a bolo di gadolinio (acido gadopentetico e sale dimegluminico, Magnevist; Schering, Berlin, Germania) 0,1 mmol/kg somministrato ad un flusso di $2 \mathrm{ml} / \mathrm{s}$, seguito da un bolo di $20 \mathrm{ml}$ di soluzione fisiologica.

\section{Analisi dei dati}

Tutti gli esami sono stati analizzati da due radiologi esperti nell'interpretazione di esami RM della mammella. I radiologi non erano a conoscenza della tecnica con cui era stato eseguito l'esame. Durante la valutazione degli esami RM erano a disposizione le immagini degli esami convenzionali precedentemente eseguiti, quali la mammografia e l'ecografia. Sono state valutate da ciascun osservatore le caratteristiche morfologiche della lesione, quali, la forma (rotonda, ovale, irregolare, o stellata), i margini (regolari, irregolari, o spiculati) e l'architettura interna (enhancement omogeneo, eterogeneo, o presenza di setti interni ipointensi). Le lesioni che hanno mostrato un potenziamento del segnale nelle acquisizioni dinamiche post-MdC sono state identificate nelle immagini sottratte. Per la valutazione del rapporto intensità segnale/tempo (Is/t) sono state disegnate manualmente delle regioni di interesse (ROI) $(3 \times 3$ pixels) all'interno delle lesioni sospette in corrispondenza dell'area di maggior enhancement. La valutazione quantitativa della percentuale di enhancement relativo della lesione è stata calcolata secondo la seguente formula: (Intensità del segnale (IS) post-contrasto - IS pre-contrasto)/IS pre-contrasto $] \times 100(\%)$. Le caratteristiche delle curve Is/t, come la presenza di enhancement persistente (tipo 1), plateau (tipo 2) o wash-out (tipo 3), sono state analizzate come descritto altrove [12]. Le lesioni evidenziate all'esame RM sono state classificate secondo $i$ criteri BI-RADS utilizzando il Fisher score [12].

Analisi della qualità delle immagini

Per l'analisi prospettica della qualità delle immagini, tutte 
the imaging sequence or as the movement of a small portion of the imaged object. Susceptibility artefacts were defined as microscopic gradients or variations in the magnetic field strength that occur near the interfaces of substances, with different magnetic susceptibility causing dephasing of spins and frequency shifts of the surrounding tissues. RF inhomogeneities, susceptibility and motion artefacts resulted in blurring of images, poor edge delineation and image distortion. A rating of 1 (poor image quality) was assigned for cases in which there was insufficient signal intensity homogeneity, substantial image degradation due to motion and susceptibility artefacts or poor visual signal-to-noise ratio (SNR), (i.e. marked blurring without definable lesion margins and image distortion). A rating of 2 (fair) was assigned for cases in which there were moderate RF inhomogeneities, no susceptibility artefacts, moderate motion artefacts and low visual SNR (i.e. blurring but definable lesion margins, no image distortion). A rating of 3 (good) was assigned for cases in which there were mild heterogeneity changes in signal intensity across the field of view (FOV), no susceptibility artefacts, mild motion artefacts and high visual SNR (i.e. minimal blurring and no image distortion). A rating of 4 (excellent) was assigned for cases in which there were no or hardly perceivable signal intensity variations across the FOV, no susceptibility artefacts, no motion artefacts and high visual SNR (i.e. sharp lesion margins and no image distortion). The image quality score given by the readers for each sequence (i.e. T2, STIR, T1 and T1 postcontrast sequences) was averaged to give an overall image score for each examination protocol. A separate mean quality score was also evaluated for each sequence. The data obtained were compared between the two protocols.

\section{Statistical analysis}

Owing to the nonnormal distribution of most variables, nonparametric statistical methods (pairwise Wilcoxon test) were used to compare both the image quality scores and the relative enhancement rates obtained with the two imaging protocols. Two-tailed $p$ values were calculated. For statistical evaluation of differences between the qualitative features of the SI/time curves achieved with the two protocols an exact Wilcoxon signed rank test for dependent samples was performed. Differences with $p<0.05$ were considered significant. All statistical analyses were performed with a commercially available software (Graphpad Prism version 4.0).

\section{Results}

The readers found 64 lesions in 31 patients. Nineteen patients had a total of 27 malignant lesions. In the remaining 12 patients, 37 benign lesions were identified ( 29 fibroade- le immagini sono state trasferite ad una workstation dove sono state visualizzate con l'idonea finestra. Le immagini sono state visualizzate in doppio per favorire il confronto diretto tra le immagini ottenute dall'applicazione della tecnica convenzionale e quelle ottenute mediante tecnica SENSE. La qualità delle immagini è stata soggettivamente valutata attraverso l'attribuzione di un punteggio da 1 (qualità delle immagini scarsa) a 4 (qualità delle immagini eccellente) in base alla presenza o all'assenza di artefatti da disomogeneità del campo magnetico, movimento e artefatti da suscettibilità magnetica. Gli artefatti da disomogeneità del campo magnetico sono definiti come la presenza di una indesiderata variazione dell'intensità di segnale nell'immagine dovuta a non uniformità del campo $B_{1}$ o a non uniforme sensibilità della bobina di ricezione. Gli artefatti da movimento (come il movimento della paziente, movimenti respiratori o da battito cardiaco e pulsazioni vascolari) sono state definite sia come il movimento dell'intero oggetto durante l'acquisizione della sequenza sia come il movimento di parte di esso. Gli artefatti da suscettibilità sono stati definiti come gradienti microscopici o variazioni nell'intensità del campo magnetico che si verificano a livello delle interfacce di tessuti aventi differente suscettibilità magnetica, causando un defasamento degli spins e uno shift nelle frequenze di risonanza dei tessuti circostanti. Le disomogeneità del campo magnetico, la suscettibilità e gli artefatti da movimento producono immagini sfumate, scarsa delineazione dei margini e distorsione delle immagini. Un punteggio di 1 (scarsa qualità delle immagini) è stato assegnato in caso di insufficiente omogeneità del segnale, significativa degradazione delle immagini da movimento o da artefatti da suscettibilità, o basso rapporto visivo segnale/rumore (SNR) (es. marcata sfumatura in assenza di margini definiti della lesione e distorsione dell'immagine). Un punteggio di 2 (sufficiente) è stato attribuito in caso di moderata disomogeneità del campo magnetico, senza artefatti da suscettibilità, moderati artefatti da movimento e basso SNR visivo (es. margini della lesione sfumati seppure evidenziabili). Un punteggio di 3 (buono) è stato assegnato nei casi in cui si è osservata una tenue disomogeneità dell'intensità di segnale nel campo di vista, non evidenti artefatti da suscettibilità, artefatti da movimento di media entità ed elevato SNR visivo (es. minima sfumatura senza distorsione dell'immagine). Un punteggio di 4 (eccellente) è stato attribuito ai casi in cui non si sono riscontrati o comunque erano scarsamente percettibili variazioni dell'omogeneità del segnale nel campo di vista dell'immagine, senza artefatti da suscettibilità, né artefatti da movimento ed elevato SNR visivo (es. margini della lesione ben definiti e non evidente distorsione dell'immagine). Lo score è stato assegno a ciascuna sequenza separatamente (T2, STIR, T1 e T1 post-contrasto) per entrambi gli esami RM. Successivamente, è stata eseguita la media degli score di tutte le sequenze valutate in 
nomas, six fibrocystic changes, one abscess and one area of adenosis). Of the 27 malignant lesions, 16 were infiltrating ductal carcinomas, five invasive lobular cancer, three mixed ductal/lobular carcinomas and three were ductal carcinoma in situ. The patients with carcinomas were 33-77 years old, and the tumour dimensions ranged from $4 \mathrm{~mm}$ to $42 \mathrm{~mm}$ (mean diameter $13 \mathrm{~mm}$ ). For the benign lesions, the patients were 18-54 years old, and the lesion dimension ranged from $15 \mathrm{~mm}$ to $53 \mathrm{~mm}$ (mean diameter $24 \mathrm{~mm}$ ).

Lesion detection and characterisation

A total 62 lesions were prospectively identified with the standard protocol. These lesions were also prospectively and independently identified using the SENSE imaging protocol. Two additional lesions were identified using the SENSE protocol in a 63-year-old woman who presented for a suspicious breast lesion in her right breast. During standard protocol examination, the subtracted images of the right breast had been degraded owing to patient motion. With the SENSE imaging protocol, two additional enhancements in the ipsilateral breast were identified (Fig. 1). The lesions were scored as BI-RADS category 5. Histological analysis revealed two ductal invasive cancers (pT1b, TNM classification). However, the demonstration of these two additional lesions using the SENSE protocol did not change management because multicentric disease had already been diagnosed with the standard imaging protocol. Three lesions identified with both the standard protocol and the SENSE protocol in three patients, who had fibrocystic disease with focal adenosis at final diagnosis, yielded three false-positive (BI-RADS 4) results. BI-RADS categories, which were given per lesion and not per breast, were identical between the two protocols in $62(97 \%)$ of 64 lesions.

\section{Kinetics analysis}

No differences were observed between mean relative enhancement rates (standard imaging protocol vs SENSE imaging protocol, $99.8 \pm 0.6$ vs $101.3 \pm 0.6, p>0.05$ ). The qualitative features of the SI/time curves, such as persistent enhancement, plateau and washout, as assessed per single lesion, were comparable between the two protocols $(p>0.05)$.

Image quality

Overall image quality scores obtained with the two techniques differed significantly (standard imaging protocol vs SENSE imaging protocol, $2.7 \pm 0.5$ vs $3.2 \pm 0.5, p<0.05$ ). In detail, a significant difference was also observed when comparing the T1 postcontrast images (standard protocol vs SENSE protocol, $2.5 \pm 0.4$ vs $3.5 \pm 0.5 p<0.001$ ) (Figs. 1, 3). The quality score of STIR images differed significantly be- modo da ottenere uno score complessivo per ciascuno dei due protocolli d'esame. I risultati ottenuti sono stati confrontati.

\section{Analisi statistica}

Per confrontare sia la qualità delle immagini che le percentuali relative di enhancement nonché le caratteristiche qualitative delle curve Is/t dei due protocolli è stato utilizzato il test non parametrico Wilcoxon dei ranghi con segno. Valori di $p<0,05$ sono stati considerati significativi. Tutte le analisi statistiche sono state eseguite con un software commercialmente disponibile (Graphpad Prism version 4.0).

\section{Risultati}

Sono state individuate 64 lesioni in 31 pazienti. Diciannove pazienti presentavano un totale di 27 lesioni maligne. Nelle rimanenti 12, sono state diagnosticate 37 lesioni benigne (29 fibroadenomi, 6 alterazioni fibro-cistiche, 1 ascesso e 1 area di adenosi). Delle 27 lesioni maligne, 16 sono risultate carcinoma duttale infiltrante, 5 carcinoma lobulare invasivo, 3 forme miste duttale/lobulare e 3 carcinomi in situ. Le pazienti con carcinoma mammario avevano un'età compresa tra 33 e 77 anni e le dimensioni del tumore variavano tra $4 \mathrm{~mm}$ e $42 \mathrm{~mm}$ (diametro medio $13 \mathrm{~mm}$ ). Relativamente alle lesioni benigne, le pazienti presentavano età compresa tra 18 e 54 anni e dimensioni delle lesioni comprese tra $15 \mathrm{~mm}$ e $53 \mathrm{~mm}$ (diametro medio $24 \mathrm{~mm}$ ).

Individuazione e caratterizzazione delle lesioni

Un totale di 62 lesioni sono state identificate con il protocollo standard. Queste lesioni sono state prospetticamente e indipendentemente identificate mediante protocollo SENSE. Due ulteriori lesioni sono state individuate utilizzando immagini ottenute con tecnica SENSE in una donna di 63 anni che presentava una lesione sospetta al seno destro. Durante l'acquisizione del protocollo d'esame standard, le immagini sottratte del seno destro sono risultate degradate in termini qualitativi a causa di artefatti da movimento della paziente. Con il protocollo SENSE sono state identificate due aree aggiuntive di enhancement nel seno destro (Fig. 1). Tali lesioni sono state classificate nella categoria 5 in accordo con la classificazione BI-RADS. L'esame istologico ha rivelato due tumori duttali invasivi ( $p T 1 b$, classificazione TNM). Tuttavia, la dimostrazione di queste due foci additivi mediante l'utilizzo del protocollo SENSE non ha modificato il trattamento della paziente poiché una malattia multicentrica era già stata diagnosticata con il protocollo di imaging convenzionale. Tre lesioni riscontrate in 3 pazienti con 

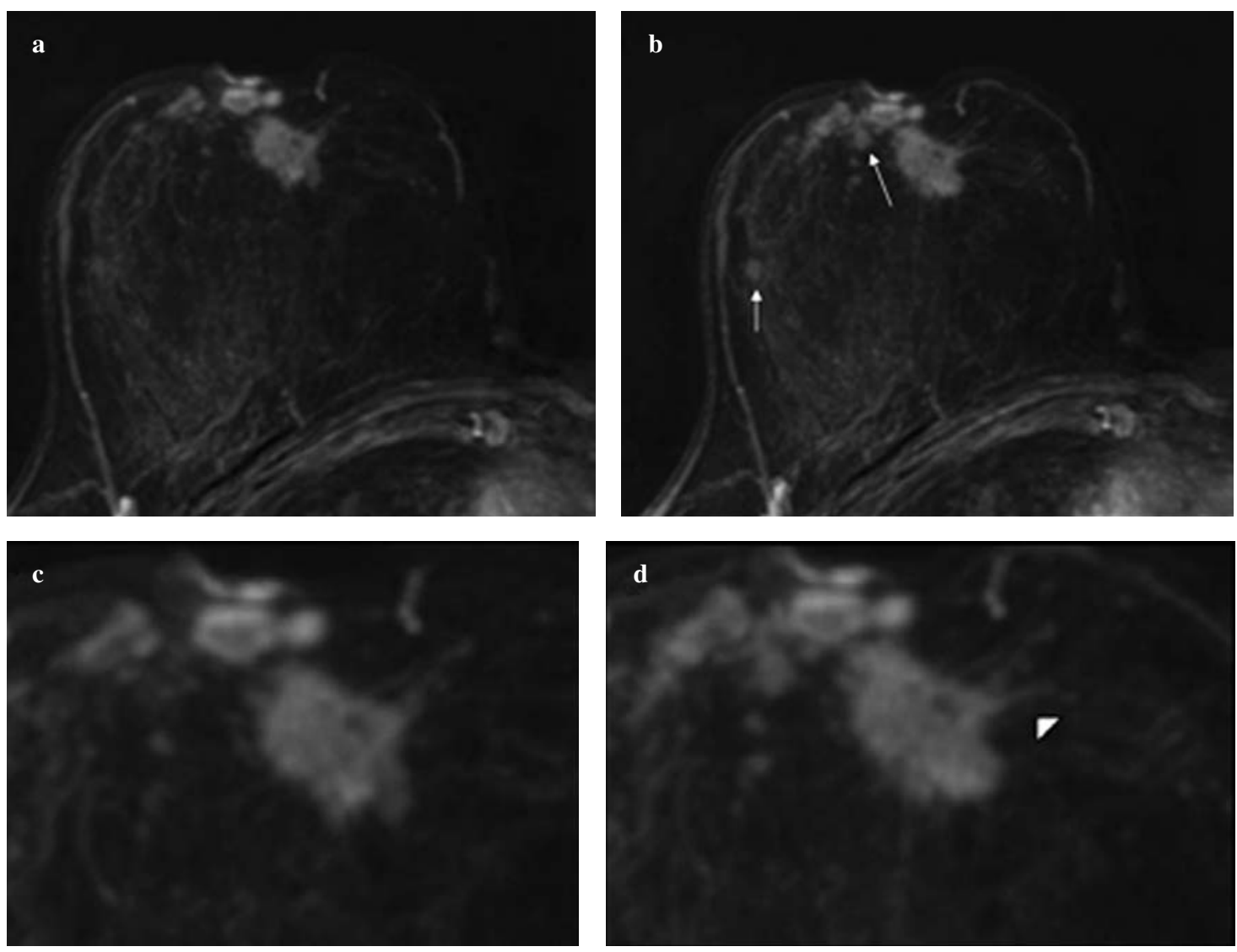

Fig. 1a-d Multicentric ductal invasive cancer in 55-year-old woman. a Dynamic subtraction magnetic resonance (MR) image of first postcontrast acquisition of conventional 2D gradient echo, (matrix , 256×256, temporal resolution $\leq 80 \mathrm{~s}$ ). b Dynamic subtraction MR image of first postcontrast acquisition of sensitivity-encoding (SENSE) imaging examination protocol (matrix, $512 \times 512$ with temporal resolution $\leq 70 \mathrm{~s}$ ). c,d Close-up views of (a) and (b), respectively. Large ductal invasive cancer in the upper inner quadrant and smaller lesions in the upper outer quadrant are seen (a). These lesions plus additional enhancing lesions (arrows) are seen with the SENSE imaging examination protocol (b). Moreover, lesion spicules were more defined with SENSE imaging examination protocol (d) (arrowhead).

Fig. 1a-d Donna di 55 anni con carcinoma duttale infiltrante multicentrico. a Immagine RM sottratta della prima acquisizione dinamica dopo mezzo di contrasto, ottenuta con protocollo convenzionale $2 D$ GE (matrice $256 \times 256$, risoluzione temporale $\leq 80 \mathrm{~s}$ ). $\boldsymbol{b}$ Immagine RM sottratta della prima acquisizione dinamica dopo mezzo di contrasto ottenuta con protocollo SENSE (matrice 512×512, risoluzione temporale $\leq 70$ s). c,d Particolari ingranditi della lesione, rispettivamente di $\boldsymbol{a}$ e $\boldsymbol{b}$. Nell' immagine a si riconosce nel quadrante supero-interno della mammella destra un grossolano processo espansivo ed un'altra lesione più piccola nel quadrante supero-esterno. Nella sequenza SENSE si riconoscono, oltre queste lesioni, ulteriori focolai neoplastici (b, frecce). Inoltre i margini spiculari sono meglio definiti nell'immagine acquisita con il protocollo SENSE (d, teste di freccia).

tween the two protocols (standard imaging protocol vs SENSE imaging protocol, $2.7 \pm 0.3$ vs $3.1 \pm 0.4, p<0.001$ ) (Fig. 4). On the countrary, the mean image quality score for the $\mathrm{T} 1$ and $\mathrm{T} 2$ morphological sequences were comparable (T1, standard imaging protocol vs SENSE imaging protocol, 3.0 \pm 0.4 vs $3.1 \pm 0.4, p>0.05 ; \mathrm{T} 2$, standard imaging protocol vs SENSE imaging protocol, $3.0 \pm 0.4$ vs $3.2 \pm 0.4, p>0.05$ ).

\section{Discussion}

In our study, we compared conventional breast MRI with breast MRI acquired with the SENSE technique with a 1.5$\mathrm{T}$ scanner in the same patients on the basis of image quali- patologia fibrocistica, che all'esame istologico sono risultate essere aree focali di adenosi, sia con il protocollo standard che con il protocollo SENSE sono risultati falsi positivi (BI-RADS 4). Le categorie BI-RADS, assegnate per lesione e non per seno, sono risultate identiche nei due protocolli in 62/ 64 lesioni (97\%).

\section{Analisi cinetica}

Non sono state osservate significative differenze tra le percentuali relative medie di enhancement (protocollo standard vs protocollo SENSE, 99,8 $\pm 0,6$ vs 101,3 $\pm 0,6, p>0,05$ ). Le caratteristiche qualitative della curva Is/t, quali persistente enhancement, plateau e washout determinate per 

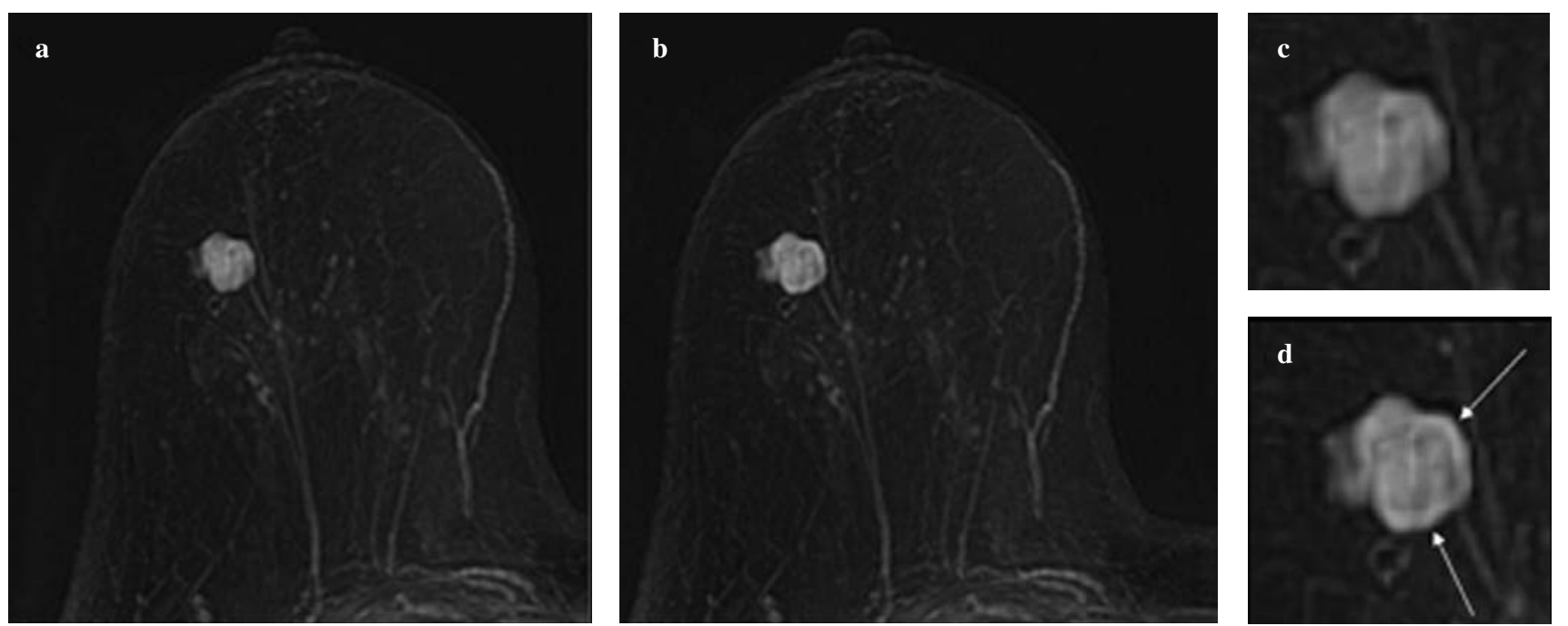

Fig. 2a-d Fibroadenoma in 47-year-old woman. a Dynamic subtraction magnetic resonance (MR) image of first postcontrast acquisition of conventional 2D gradient echo (matrix, 256×256, temporal resolution $\leq 80$ s). b Dynamic subtraction MR image of first postcontrast acquisition of sensitivity-encoding (SENSE) imaging examination protocol (matrix, $512 \times 512$ with temporal resolution $\leq 70$ s). c,d Close-up views of (a) and (b), respectively. The typical well-defined border and nonenhancing internal septations of the fibroadenoma are better defined with the SENSE imaging protocol (b) and (d) (arrows).

Fig. 2a-d Fibroadenoma in una donna di 47 anni. a Immagine RM sottratta della prima acquisizione dinamica dopo mezzo di contrasto, ottenuta con protocollo convenzionale $2 D$ GE (matrice $256 \times 256$, risoluzione temporale $\leq 80 \mathrm{~s}$ ). $\boldsymbol{b}$ Immagine RM sottratta della prima acquisizione dinamica dopo mezzo di contrasto ottenuta con protocollo SENSE (matrice $512 \times 512$, risoluzione temporale $\leq 70 \mathrm{~s}$ ). $\boldsymbol{c}, \boldsymbol{d}$ Particolari ingranditi della lesione, rispettivamente di $\boldsymbol{a}$ e $\boldsymbol{b}$. Il tipico aspetto RM del fibroadeonoma, con margini ben definiti e setti interni che non mostrano incremento dell'intensità del segnale, appaiono meglio riconoscibili sull'immagine ottenuta con protocollo di studio SENSE.
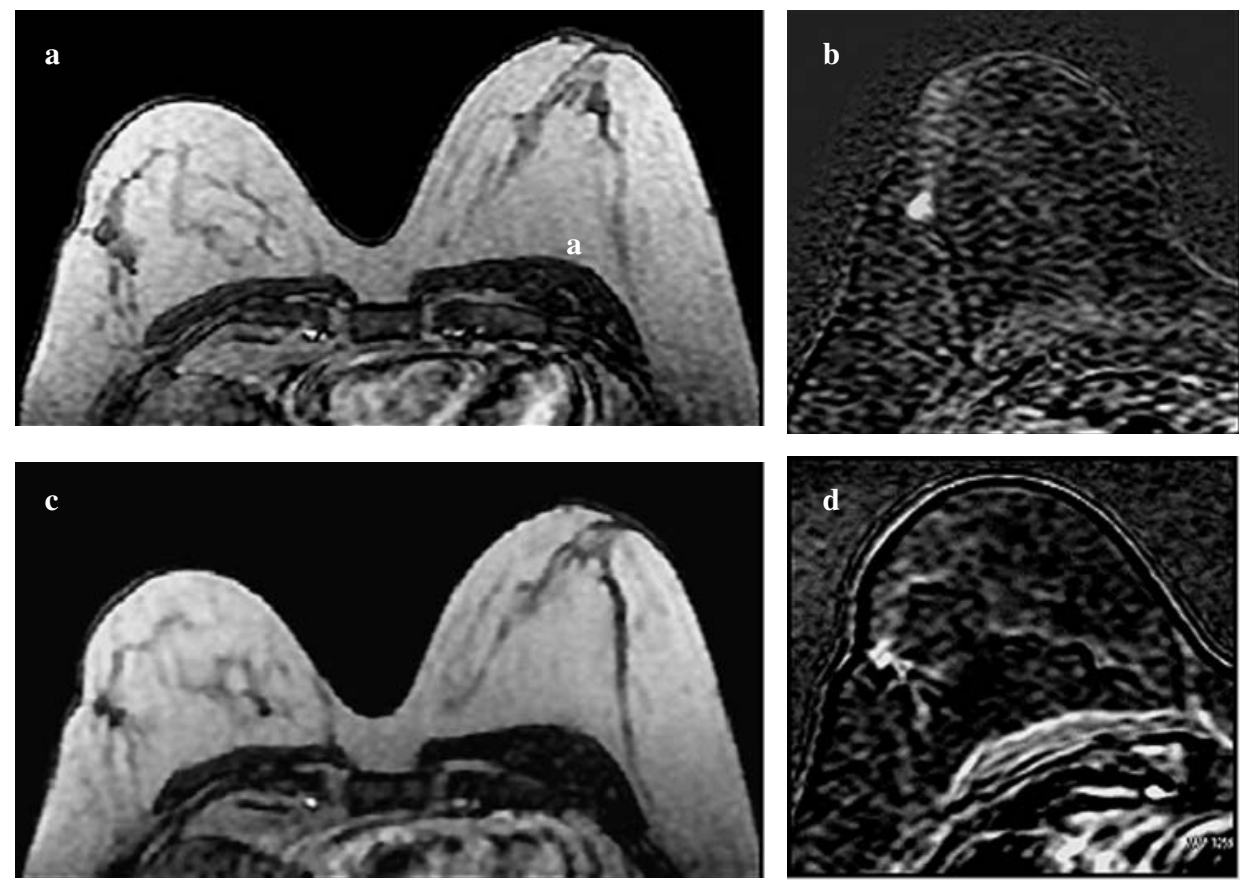

Fig. 3a-d Axial precontrast T1 magnetic resonance (MR) images and corresponding subtracted images for a 44-year-old woman with previous breast cancer who underwent MR imaging for follow-up. a,b Standard dynamic protocol (matrix, 256 $\times 256$, temporal resolution $\leq 80$ s): the lesion appear as a nodular mass with smooth borders on the precontrast image (a); first postcontrast subtracted image (b). c,d Dynamic protocol with sensitivity-encoding (matrix, $512 \times 512$, temporal resolution $70 \mathrm{~s}$ ); spicules were visualised at the site of enhancing lesion. Excisional biopsy was performed revealing invasive ductal carcinoma.

Fig. 3a-d Immagini RM assiali T1-dipendenti pre e post-contrastografiche di una donna di 44 anni, già operata di carcinoma mammario, che ha effettuato l'esame per controllo. a,b Protocollo RM dinamico convenzionale (matrice $256 \times 256$, risoluzion temporale $\leq 80$ s). La lesione appare come una massa nodulare con margini lisci sia nell'immagine pre-contrastografica $(\boldsymbol{a})$, sia in quella dopo mezzo di contrasto $(\boldsymbol{b})$. c, $\boldsymbol{d}$ Sulle immagini ottenute con protocollo RM dinamico SENSE (matrice $512 \times 512$. risoluzione temporale $\leq 70$ s) sono evidenti spicule a livello della lesione. La biopsia escissionale ha rilevato un carcinoma duttale infiltrante. 

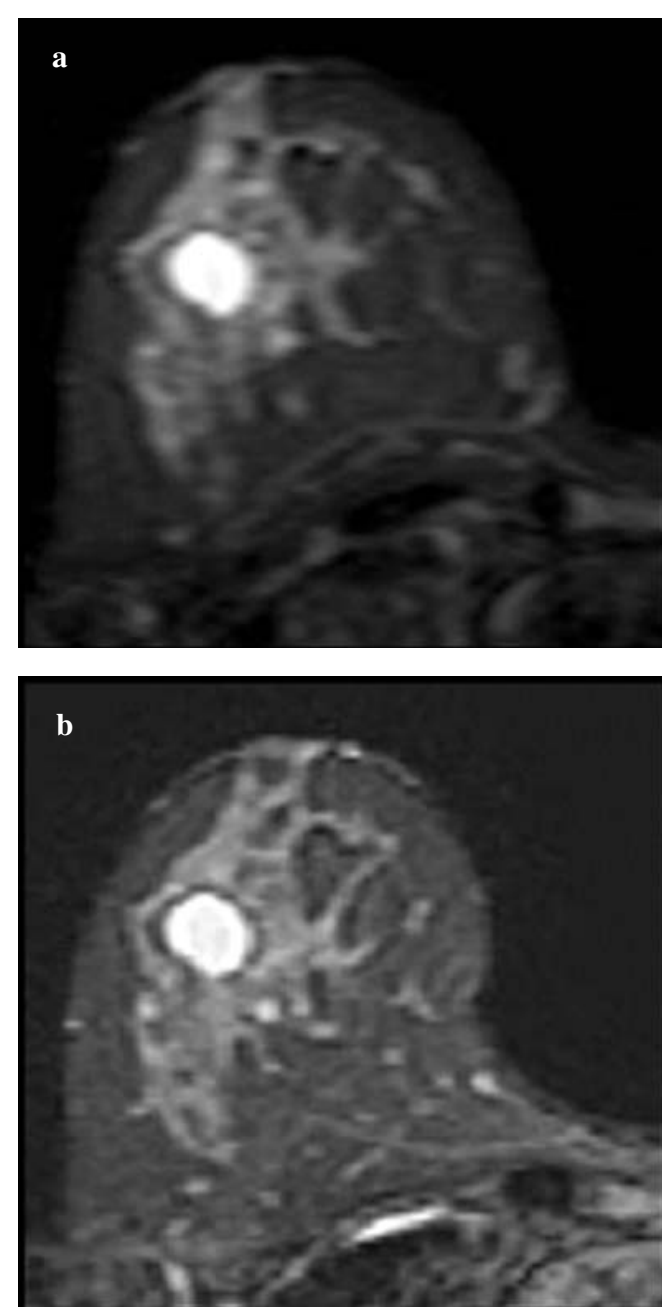

Fig. 4a,b Short tau inversion recovery (STIR) sequence in 34-year-old woman with a benign cystic lesion. a Note smooth borders of lesion on standard pulse sequence and the poor anatomical detail of the surrounding fibroglandular tissue. b Well-defined borders and the high anatomic detail of fibroglandular tissue become apparent on pulse sequence with sensitivity-encoding.

Fig. $4 a, b$ Sequenza RM Short tau inversion recovery (STIR) in una donna di 34 anni con una lesione cistica della mammella destra. a Nella sequenza convenzionale la lesione mostra margini lisci e si nota uno scarso dettaglio anatomico delle strutture fibro-ghiandolari circostanti. $\boldsymbol{b}$ All'immagine RM ottenuta con sequenza SENSE si rileva un maggiore dettaglio anatomico del tessuto fibroghiandolare ed una maggiore definizione dei margini della lesione.

ty and kinetics analysis. Mean relative enhancement rates and qualitative features of the SI/time curves were also comparable between conventional and SENSE imaging protocols $(p>0.05)$. However, the SENSE imaging protocol was superior to conventional imaging regarding overall image quality $(p<0.05)$; in particular, a significant difference was observed regarding both the T1 postcontrast image quality scores $(p<0.001)$ and the STIR image quality scores $(p<0.001)$. Breast MRI is increasingly used in addition to ciascuna lesione, sono risultate simili nei due protocolli $(p>0,05)$.

Qualità dell'immagine

Il punteggio complessivo assegnato alla qualità complessiva dell'immagine ottenuto con il protocollo SENSE è risultato superiore rispetto al protocollo convenzionale (proto-

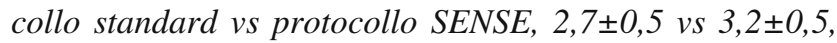
$p<0,05)$. In particolare, una differenza statisticamente significativa è stata osservata per le immagini T1 post-contrasto (protocollo standard vs protocollo SENSE, 2,5 $\pm 0,4$ vs 3,5 $\pm 0,5 p<0,001$ ) (Figg. 1-3). Ugualmente, il punteggio ottenuto per immagini STIR mostra una superiorità del protocollo SENSE (protocollo standard vs protocollo SENSE, $2,7 \pm 0,3$ vs 3,1 $\pm 0,4, p<0,001$ ) (Fig. 4). Al contrario, la qualità delle immagini morfologiche T1 e T2 è risultata sovrapponibile (T1, protocollo standard vs protocollo SENSE, $3,0 \pm 0,4$ vs 3,1 $\pm 0,4, p>0,05 ; T 2$, protocollo standard vs

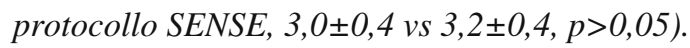

\section{Discussione}

In questo studio abbiamo confrontato in termini di qualità di immagine e analisi cinetica dell'enhancement, l'imaging RM convenzionale delle mammelle con l'imaging RM ottenuto mediante l'impiego della tecnica SENSE nello stesso gruppo di pazienti utilizzando uno scanner RM 1,5 T. La qualità delle immagini ottenute con il protocollo SENSE è risultato superiore rispetto al protocollo $R M$ convenzionale $(p<0,05)$. In particolare, differenze significative sono state osservate nei punteggi assegnati alle immagini $T 1$ post contrasto $(p<0,001)$ e alle immagini STIR $(p<0,001)$. Le percentuali medie relative di enhancement e le caratteristiche qualitative delle curve Is/t, ottenute con i due diversi protocolli d'esame sono risultate sovrapponibili ( $p>0,05)$. La RM della mammella è sempre più frequentemente utilizzata in associazione alle modalità di imaging convenzionale quale la mammografia e l'ecografia mammaria per la diagnosi del carcinoma della mammella [13-15]. Benché l'elevata sensibilità della RM sia nota, la sua limitata specificità continua ad essere problematica [16]. Un esame RM dinamico della mammella per essere affidabile dal punto di vista diagnostico deve essere acquisito con una elevata risoluzione spaziale in un intervallo di tempo compreso tra 60-120 s. A differenza della risoluzione temporale (per cui un'ulteriore incremento della risoluzione temporale al di sotto di 60 s non comporta alcuna informazione diagnostica aggiuntiva), l'incremento della risoluzione spaziale è estremamente vantaggioso, purché si mantengano accettabili valori di SNR [17-19]. Con la tecnica SENSE, a differenza di quanto avviene utilizzando bobine phased array, i singoli elementi del- 
conventional breast imaging modalities, such as mammography and breast US [13-15]. Whereas the excellent sensitivity of breast MRI is well known, its limited specificity continues to be problematic [16]. To be reliable, a dynamic breast MRI examination should have a spatial resolution as high as possibly achievable within $60-120$ s. Unlike temporal resolution (in which a further increase beyond the 60s limit does not bring any additional diagnostic information), improving spatial resolution is highly advantageous provided acceptable SNR levels are maintained [17-19]. With the SENSE technique, unlike what happens with phased-array coils, the coil elements are not used to cover separate anatomical regions to increase the SNR but are used to simultaneously measure the same region, with an increase in scan speed [20, 21]. The SENSE reconstruction algorithm separates the superimposed signals using information on the individual coil sensitivities and restores the full FOV image.

In general, SENSE reduces scanning time at the expense of a decrease in SNR that is equivalent to reducing the number of excitations. Although SENSE imaging is fully integrated in routine clinical practice for many body and MRI angiography applications, its use in breast MRI is lagging behind. Van den Brink and colleagues using SENSE combined with a $2 \mathrm{D}$ gradient echo dynamic pulse sequence with a 1.5-T scanner were able to increase the spatial resolution to a 400/512 imaging matrix, keeping the temporal resolution at $1 \mathrm{~min}$ and without affecting image contrast. They concluded that the yield in spatial resolution translated in an almost proportional increase of diagnostic specificity [22]. In our study, the gain in image acquisition speed obtained employing SENSE was invested in improving spatial resolution with a 3D high-matrix imaging. Indeed, compared with 2D sequences, 3D pulse sequences offer a higher SNR, which can be traded for improving spatial resolution (increased thinner section thickness or higher matrix). However, despite the obvious technical advantages of 3D imaging, 2D sequences are generally preferred by most radiologists. This is because 3D imaging has a lower temporal resolution and suffers significantly more from image degradation due to all kinds of artefacts, including field inhomogeneities and motion artefacts [19]. However, it is recognised that parallel imaging is able to reduce field inhomogeneities and motion artefacts [20, 21]. Indeed, in our study, by using the SENSE technique combined with 3D pulsed sequences, while preserving kinetic data, we were able to obtain images with a higher quality score compared with the standard 2D protocol without SENSE. Our data are in accordance with Friedman et al. [23]. These authors evaluated the diagnostic accuracy of three different 3D dynamic contrast-enhanced breast MRI protocols acquired with SENSE technique performed with a 1.5-T MR scanner. In their conclusions, they state that the SENSE technique has resulted in fewer recalls for breathing la bobina non sono utilizzati per coprire differenti regioni anatomiche per incrementare il rapporto segnale-rumore (SNR), ma sono utilizzate per campionare il segnale proveniente dalla stessa area, con il conseguente aumento della velocità di acquisizione [20, 21]. L'algoritmo di ricostruzione SENSE separa i segnali sovrapposti mediante le informazioni relative alla sensibilità di ogni singolo elemento della bobina e ricostruisce l'immagine dell'oggetto.

In generale, la tecnica SENSE riduce il tempo di scansione a discapito di una diminuzione del SNR, che equivale ad una riduzione del numero di eccitazioni. Benché l'imaging SENSE sia ampiamente impiegato nella pratica clinica per la body e l'angio-RM, il suo utilizzo per la mammella non è universalmente accettato. Van den Brink et al. [22] utilizzando la tecnica SENSE associata a sequenze pulsate $2 D$ gradient echo dinamiche con uno scanner a 1,5 $T$, sono stati in grado di aumentare la risoluzione spaziale utilizzando una matrice pari a 400/512, mantenendo la risoluzione temporale $\leq 1$ minuto senza modificare il contrasto dell'immagine. Gli autori hanno concluso che l'aumento della risoluzione spaziale si traduce in un incremento della specificità diagnostica [22]. Nel nostro studio il guadagno in termini di rapidità di acquisizione ottenuto mediante l'utilizzo della tecnica SENSE è stato impiegato per aumentare la risoluzione spaziale utilizzando sequenze $3 D$ con matrice elevata e con spessore di strato sottile. Le sequenze $3 D$ offrono, rispetto alle sequenze $2 D$, un maggiore $S N R$, che può essere sfruttato per migliorare la risoluzione spaziale (riduzione dello spessore di strato o matrice più elevata). Tuttavia, malgrado gli evidenti vantaggi dell'imaging 3D, le sequenze $2 D$ sono generalmente preferite. Questo perché l'imaging $3 D$ ha una minore risoluzione temporale e risente in misura significativamente superiore della degradazione della qualità dell'immagine dovuta a qualunque tipo di artefatto, compresi gli artefatti da disomogeneità del campo magnetico e gli artefatti da movimento rispetto alle sequenze 2D [19]. L'impiego dell'imaging parallelo è in grado di ridurre le disomogeneità del campo e gli artefatti da movimento [20, 21]. Infatti, come dimostrato nel nostro studio, l'impiego della tecnica SENSE in associazione a sequenze pulsate $3 D$, preservando i dati cinetici, ha permesso di ottenere immagini di qualità superiore in confronto a quelle ottenute con protocollo $2 D$ standard senza SENSE. I nostri dati sono in accordo con Friedman et al. [23]. Questi autori hanno valutato l'accuratezza diagnostica di tre differenti protocolli dinamici $3 D$ per lo studio RM della mammella acquisiti con tecnica SENSE ed eseguiti con apparecchiatura RM 1,5 T. Nelle loro conclusioni hanno riportato che l'utilizzo della tecnica SENSE ha diminuito il numero dei richiami delle pazienti per esami RM inadeguati grazie alla diminuzione della presenza di artefatti da movimento legati alla respirazione ed al battito cardiaco o alla cattiva visualizzazione dei cavi ascellari. 
and cardiac motion artefacts and incomplete visualisation of the axilla.

Finally, not surprisingly, in our study, a mean higher image quality score was obtained for STIR sequences acquired with SENSE imaging $(p<0.001)$. Indeed, better contrast was obtained with SENSE in sequences with transient behaviour, such as inversion recovery sequences. In the time period when the background signal crosses zero, more data can be obtained with SENSE, resulting in a better background suppression [20].

\section{Conclusions}

In conclusion, our results suggest that the SENSE imaging protocol applied in our study provided better image quality compared with conventional imaging. Despite the limited number of patients in this evaluation, our results are encouraging, and high-spatial-resolution SENSE imaging protocols appear to constitute an attractive alternative to conventional sequences for contrast-enhanced MRI of the breast using 1.5-T MR scanners.
Nel nostro studio, abbiamo inoltre osservato che la qualità delle immagini STIR acquisite con il protocollo SENSE è risultato significativamente superiore rispetto al protocollo standard $(p<0,001)$. Ciò non sorprende, infatti, con la tecnica SENSE si ottiene un miglioramento del contrasto dell'immagine nelle sequenze di imaging inversion recovery, quale la STIR. Nell'intervallo di tempo in cui il segnale di base oltrepassa lo zero, con la tecnica SENSE si possono ottenere molti più dati, con una conseguente migliore soppressione di fondo [20].

\section{Conclusioni}

In conclusione, i nostri risultati indicano che il protocollo di imaging con tecnica SENSE applicato nel nostro studio, è superiore, in termini di qualità di immagine, rispetto all'imaging RM convenzionale. Malgrado il limitato numero di pazienti nello studio, $i$ nostri risultati suggeriscono che l'imaging SENSE ad elevata risoluzione spaziale costituisce una interessante alternativa allo studio RM convenzionale della mammella utilizzando un'apparecchiatura RM 1,5 T.

\section{References/Bibliografia}

1. Kuhl CK (2000) MRI of breast tumors. Eur Radiol 10:46-58

2. Helbich TH (2000) Contrast-enhanced magnetic resonance imaging of the breast. Eur J Radiol 34:208-219

3. Goscin CP, Berman CG, Clark RA (2001) Magnetic resonance imaging of the breast. Cancer Control 8:399-406

4. Schnall MD, Blume J, Bluemke DA et al (2006) Diagnostic architectural and dynamic features at breast MR imaging: multicenter study. Radiology 238:42-53

5. Schnall MD, Rosten S, Englander S et al (2001) A combined architectural and kinetic interpretation model for breast MR images. Acad Radiol 8:591-597

6. Nunes LW, Schnall MD, Orel SG (2001) Update of breast MR imaging architectural interpretation model. Radiology 219:484-494

7. Kuhl CK, Schild HH, Morakkabati N (2005) Dynamic bilateral contrastenhanced MR imaging of the breast: trade-off between spatial and temporal resolution. Radiology 236:789-800
8. Nunes LW, Schnall MD, Siegelman ES et al (1997) Diagnostic performance characteristics of architectural features revealed by high spatial-resolution MR imaging of the breast. AJR Am J Roentgenol 169:409-415

9. Kuhl CK, Jost P, Morakkabati N et al (2006) Contrast-enhanced MR Imaging of the breast at 3.0 and $1.5 \mathrm{~T}$ in the same patients: initial experience. Radiology 239:666-676

10. Ikeda T, Monzawa S, Komoto K (2004) Performance assessment of phasedarray coil in breast MR imaging. Magn Reson Med Sci 3:39-43

11. Glockner JF, Hu HH, Stanley DW et al (2005) Parallel MR imaging: a user's guide. Radiographics 25:1279-1297

12. Baum F, Fischer U, Vosshenrich R (2002) Classification of hypervascularized lesions in CE MR imaging of the breast. Eur Radiol 12:1087-1092

13. Berg WA, Gutierrez L, NessAiver MS et al (2004) Diagnostic accuracy of mammography, clinical examination, US, and MR imaging in preoperative assessment of breast cancer. Radiology 233:830-849
14. Sardanelli F, Lozzelli A, Fausto A (2003) MR imaging of the breast: indications, established technique, and new directions. Eur Radiol 13:28-36

15. Bluemke DA, Gatsonis CA, Chen MH et al (2004) Magnetic resonance imaging of the breast prior to biopsy. JAMA 292:2735-2742

16. Sardanelli F, Giuseppetti GM, Panizza $\mathrm{P}$ et al; Italian Trial for Breast MR in Multifocal/Multicentric Cancer (2004) Sensitivity of MRI versus mammography for detecting foci of multifocal, multicentric breast cancer in fatty and dense breasts using the wholebreast pathologic examination as a gold standard. AJR Am J Roentgenol 183:1149-1157

17. Kuhl CK, Mielcareck P, Klaschik S et al (1999) Dynamic breast MR imaging: are signal intensity time course data useful for differential diagnosis of enhancing lesions? Radiology 211:101-110

18. Tozaki M, Igarashi T, Matsushima S et al (2005) High-spatial-resolution MR imaging of focal breast masses: interpretation model based on kinetic and morphological parameters. Radiat Med 23:43-50 
19. Kuhl CK (2005) Dynamic breast magnetic resonance imaging. Breast MRI. Springer, New York

20. Glockner JF, Hu H, Stanley DW et al (2005) Parallel MR Imaging: a user's guide. Radiographics 25:1279-1297
21. Katscher U, Börnert P (2006) Parallel RF transmission in MRI. NMR Biomed 19:393-400

22. van den Brink JS, Watanabe Y, Kuhl CK et al (2003) Implications of SENSE MR in routine clinical practice. Eur $\mathbf{J}$ Radiol 46:3-27
23. Friedman PD, Swaminathan SV, Smith $R$ (2005) SENSE imaging of the breast. AJR Am J Roentgenol 184:448-451 